\title{
The politics of river basin organizations: institutional design choices, coalitions, and consequences
}

\author{
Dave Huitema $^{1,2}$ and Sander Meijerink ${ }^{3}$
}

\begin{abstract}
The idea that ecosystem management should be approached at the bioregional scale is central to the thinking on adaptive governance. Taken to the domain of water management, a bioregional approach implies the foundation of river basin organizations (RBOs), a notion that has been warmly welcomed by scholars and practitioners alike. However, it appears that river basin organizations come in various shapes and sizes, their intended foundation often leads to resistance, and their actual performance is understudied. Through this special feature we seek to advance the state of our knowledge in this respect. Through this introduction we lay the foundation for the case studies that follow in the special feature and for the conclusions. We do so by presenting a worked typology of river basin organizations. This typology helps us differentiate between various kinds of proposals that are all referred to as river basin organizations, but that are actually quite different in nature. In addition, in this introduction we present an approach to dissecting the inevitable political debates that ensue once a proposal to found a river basin organization is made, something that is often ill understood by the proponents of river basin organizations. After this, we explain the criteria that one could use to assess the performance of river basin organizations that actually come into being. Although the thinking in adaptive governance is strongly concerned with ecological effectiveness, we do show that other criteria can be applied too. Finally, we briefly introduce the various contributions to the special feature.
\end{abstract}

Key Words: bioregional approach; institutional design, institutional performance; river basin organizations; water governance

\section{SHIFTS IN WATER GOVERNANCE}

Water and human development are inextricably linked. Human settlement tends to concentrate along rivers and coasts. This is because waters offer fertile soils, opportunities for irrigation, and possibilities for transport and trade. To use the possibilities of the water as much as possible and to reduce the risks associated with human settlement close to water, social organization and systems of governance are required. Arguably because water is such a crucial element in societal development, many ancient societies had to make decisions about their water management organizations early. The degree to which organizations founded for water management influence later traditions of governing is under debate. There is an old claim that the organization of water management, which can be centralized and focused on large scale infrastructure or rather decentralized and focused on local management, determined the governance system of entire empires (Wittfogel 1957). But others suggest that it is rather the other way around, in the sense that societies with accomplished hierarchical governance structures were better able to develop centralized infrastructures for managing water and thus to control their water environment.

Whatever the protracted history of water management and its importance for broader historical patterns of governance that have emerged since ancient times, the advent of the nation state - depending on the country in question this took place in most cases in the 18th, 19th, or 20th century-was a significant development, and in most cases a serious break from the traditions of the past. The nation state, built upon concerted efforts to change social cultural preferences (so-called nation building) through the crafting of new bonds of affiliation and a retelling of history, implied a nationalization of responsibilities that were previously at the local level, and has, since it took place, shaped the division of responsibilities of what we now appropriately call the inter"national" level. Water management was fully implied in the process of nation building. In many countries, new water works served to make fragmented countries more integrated by physically connecting previously separate parts. Various such projects became focal points for nation building by showing highly developed engineering skills. New organizations for water management were founded that operated at the national scale. In the process of nationalization, previously established communal and private elements of the governance system were overhauled. In many cases this effectively meant an expropriation of rights from private owners to state bureaucracies, who often started using their decision power to further certain economic interests, be it newly emerging industries that were allowed to use the pollution assimilation capacity of water for the release of its waste materials, or agriculture, which until today consumes enormous amounts of freshwater for irrigation, often without being fully charged for the costs.

The process of building up the nation state had two elements that are worth mentioning here. The first is that when it took place, government institutions were often designed on the basis of a socalled classical modernist design (Hajer 2003), embedded in respective constitutions. This implied that government tasks and responsibilities would be divided over respective layers of government, usually three or four. Most of these government layers were assigned a wide set of responsibilities (general purpose governments) and because the boundaries were relatively clear cut, a certain level of so-called jurisdictional integrity was created. Nation states differ in many ways; they can be federal or unitary states, the level of centralization can differ, the formal leadership can be presidential or monarchical, the role of the judiciary can be expansive or limited, etc. In many cases however, water management tasks were allocated to general purpose government layers, and thus became part of what could be called the normal 
government apparatus. Special purpose organizations such as river basin organizations (RBOs) did not fit easily in this scheme, although in some cases, such as the Netherlands, the water boards that had existed long before the modern nation state were given a constitutional status equal to that of municipalities. A second element worth mentioning here is that in almost any new nation state, issues of control loomed large. Democratic control, especially in the form of representative democracy, has almost universal appeal and has thus become the norm for shaping control. There are however multiple models of democracy (Held 2006) and some of these models actually convey very little direct citizen control over government institutions. Regardless of the model of democracy that is applied by the elite in the new nation states, the quest for democratic control has almost always been a struggle, and the adoption of important democratic principles such as transparency, accountability, and the replacement of leaders by the polity too.

In the period from the Second World War until roughly the start of the 1980s, the role of governments in many societies across the world expanded, often for reasons associated with development of a welfare state, but usually also because this was an era of confidence in the power of centralized, planned, and rational problem solving. And the concept of the nation state, to the chagrin of some who see the nation state's sovereignty as a hindrance for addressing many of the world's problems, is still very much a key aspect in developing responses to water problems. However, the power of most nation states is slowly changing and eroding, and power is diffusing to other actors (with or without government oversight). This change, often described as a shift from government to governance, started taking place around the 1980 and is depicted in Figure 1.

Fig. 1. Shifts in governance since the 1980s.

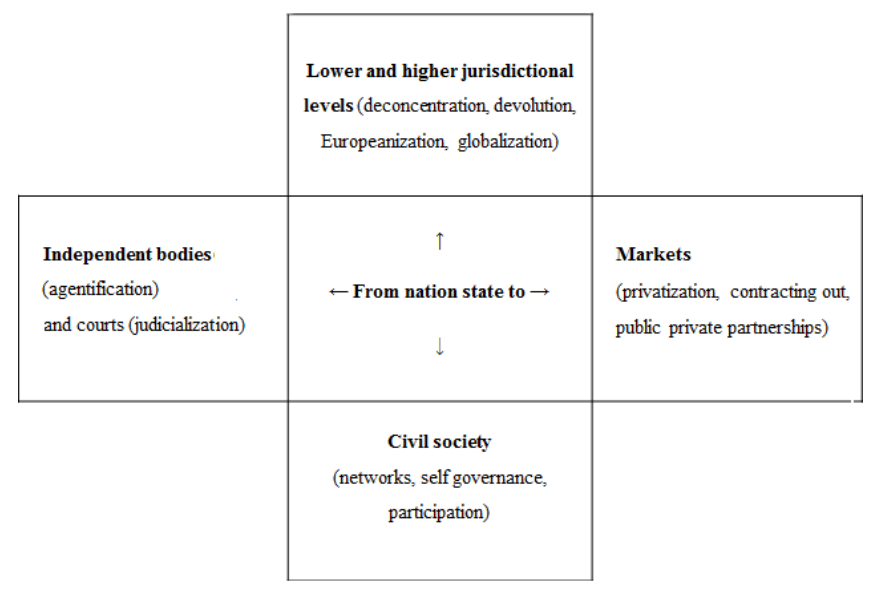

The reasons behind these shifts in governance are often debated. There is a strong ideological element in the sense that neoliberal ideas, which emphasize the strength of market initiative and the failure of government, gained currency in the 1980s. But in the same decade another influential wave of thought emerged: the one on community governance and self-governance. Both waves of thought have academic roots in economics and the political sciences. These and other social science disciplines affected each of the shifts signified here in one way or another. Authors who write about governance (e.g., Pierre and Peters 2000) also suggest a less prosaic explanation for these shifts, mainly that the nation state had grown too large to sustain itself much longer. Especially in some European countries, public spending amounted to more than half of gross domestic product, and the functioning of the ensuing big government, often founded on central control and planning, was considered suspect at best in many areas. Red tape, over-regulation, and excessive bureaucracy became rallying cries in the battle to hollow out the state (Rhodes 1996).

The increasingly global discourse on water governance (see for instance Gupta 2009), bears several traces of these bigger debates and larger scale shifts in governance. The central guiding concept of integrated water resources management (IWRM) for instance, suggests greater private sector involvement in water management, the establishment of pricing mechanisms, it assigns a large role to independent experts by suggesting the greater use of decision making tools like cost benefit analysis, it suggests more international collaboration whilst at the same time indicating the possibility for local control, and it underlines the need for greater public participation and stakeholder involvement at all levels. IWRM is often presented as a corrective to the errors of the socalled hydrological mission (see Jaspers and Gupta 2014), the spawn of large-scale engineering projects that went hand in hand with nation building and the subsequent growth of nation states and big government. The integrated aspect of IWRM is often interpreted to denote more attention to the ecological and societal impacts of water management activities, including the typical large scale projects. It also denotes a geographical emphasis, in the sense that water managers should start paying more attention to the interlinkages between upstream and downstream interventions by working on the river basin scale and founding RBOs.

IWRM is clearly a multifaceted concept and implementing each of the aspects may require an extensive job of translation from one context to another (Mukhtarov 2009) and weighting. Obviously not all aspects are equally important to water managers. It has been suggested that the so-called river basin approach (also called the water-systems approach, see, e.g., Teclaff 1967, Lundqvist et al. 1985, Mitchell 1990, Mostert 2000) is the key innovation that the water governance community is after and preferably in a form that takes away power from normal governments, that is away from elements of the nation state such as provinces, municipalities, or states. Schlager and Blomquist (2008:1) observe the following:
For the last 25 years, prescriptions of the water policy literature have centered upon two themes. The first is that "the watershed" is the appropriate scale for organizing water resource management [...]. The second is that since watersheds are regions to which political jurisdictions almost never correspond, and watershed- scale decision making structures do not usually exist, they should be created.

And the plea for river basin organizations has not been without effect. In a worldwide survey, Dinar et al. (2005) found hundreds of transboundary basin organizations. 
If one were to analyze the introduction of RBOs from the perspective of the shifts in governance noted above, it is not immediately clear how they would fit in. To some degree, most plans to found RBOs probably constitute a change in the level of governance, for instance, from the national to the international level when transboundary organizations are founded, or from the national to the regional level when basins within a country are involved. However, there are probably also instances where a river basin organization is actually a civil society type of organization, taking the shape of a water user association or water shed organization, which would imply decentralization. And, it is likely, in certain cases, that RBOs will be dominated by engineers or scientists and would thus effectively constitute independent bodies, which, given the fatigue about holistic planning, will often be special purpose in nature, meaning that they focus on water issues alone.

Such design choices, like all shifts in governance that affect the functioning of the nation state and its embedded democratic mechanisms, have multiple consequences and are thus deeply political (see Molle 2009). Our agenda in this special feature is to focus exactly on the political dimension of river basin organizations. This agenda has relevance for the debates on resilience and adaptive comanagement, in which the notion of a holistic approach at the bioregional scale plays an important role (see Desmet and Cowling 2004, Davis et al. 2006, Donovan et al. 2009, Huitema et al. 2009). Cook et al. (2016) write the following in their contribution to this special feature:

\begin{abstract}
Bioregionalism is a well-established philosophy that seeks to better connect communities with the governance of their local environment (McGinnis 1999).[...] Although definitions vary, several features of modern bioregionalism are evident relating to decision making powers, scale, participation, and knowledge use in governing environmental resources, in addition to environmental justice. For proponents, devolving powers to local communities, situated within ecologically distinct bioregions, can empower them to determine more effective environmental governance through utilizing local knowledge (Sale 1985, Aberley 1999, McGinnis 1999).
\end{abstract}

Cook et al. (2016) continue by suggesting that questions abound around the practical achievement and effectiveness of a bioregional approach, the social and economic meaning of bioregions in the real world, and around the institutional design of bioregional organizations. In this special feature, we advance this agenda that is so relevant to Ecology and Society by focusing on water specifically, and by asking a set of four interrelated questions that will guide the contributions to this special feature and that also steered a larger set of case studies reported in Huitema and Meijerink (2014) that we will also refer to here:

1. What are institutional design characteristics of river basin organizations and how were their geographical boundaries chosen?

2. Who supported and who resisted the founding or reform of river basin organizations?

3. How well do the river basin organizations function in a democratic sense and in terms of realizing coordination and environmental effectiveness, and to which degree can this performance be attributed to the institutional design of these organizations and their geographical delineation?

4. What are the implications of these findings for those who are involved in institutional design or reform processes in the water sector?

We shall attempt to answer these four questions for river basin organizations that operate within the boundaries of certain nation states, and we explicitly do not focus on transboundary basin organizations. Water management is but one of the many policy domains in which independent, special purpose organizations have been created, but for several reasons this policy domain offers particularly fertile ground for an exploration of the research questions posed above. First, there is a long and rich history of special purpose organizations in water management (compare Molle 2008 and 2009, Molle and Wester 2009; Delli Priscoli, unpublished manuscript, http://transboundarywater.geo.orst. edu/research/case studies/Documents/RiverBasinOrganizations. pdf). The history of river basin organizations makes it possible to study their evolution, to trace the impacts that various new discourses have had on their institutional design, and to draw lessons from the experiences that water managers have gained with these special purpose organizations. Second, many water problems are pressing issues. The complex relationships between land-use and water management and between upstream and downstream water users have caused serious water conflicts in many river basins and climate change might exacerbate the tensions. Because of the rapid economic development in large parts of the world along with expected climate change, both the number and the seriousness of water conflicts is expected to increase in the near future. How to design institutions that are able to deal with these issues and conflicts effectively is one of the key challenges for earth-system governance in this century. To make it clear, this introduction is a reproduction of the chapter "The Politics of River Basin Organisations. Institutional Design Choices, Coalitions and Consequences" taken from our edited book under the same title (Huitema and Meijerink 2014). Only small updates, minor changes in the reference list, and several changes in wording have occurred. Through this republication we seek to link our work more firmly to discussions in the resilience community, and our hope is that having work out in an open access arrangement helps reach the widest possible audience. Permission to republish this chapter was kindly granted by Edward Elgar Publishers (Cheltenham, UK).

With our research agenda, we follow in the footsteps of other governance scholars who have worked on river basin organizations. They have raised several issues in relation to the institution and operation of river basin organizations, which we will discuss in turn, taking cue from the arguments from Huitema et al. (2009).

First, governance scholars suggest that the boundaries of river basins are not necessarily so clear cut, evident, or even natural (Schlager and Blomquist 2008, Molle 2009). The idea of "the" river basin suggests a certain simplicity, which in reality does not exist because river basins are connected, sometimes by human intervention, and nested. This means that defining the boundaries of a basin requires choice, and this implies a role for politics. Schlager and Blomquist (2008:15-16) state the following: 


\begin{abstract}
Boundaries are multiple, overlapping, and often contested because people experience and attempt to deal with a host of problems and opportunities that vary in scale from the local to the regional. Drawing boundaries is the first step in determining who decides and how and with what effects. Different boundaries imply different decision makers and different effects.
\end{abstract}

Some communities may lose local control, whereas others may gain more control. Especially those who benefit from the current boundaries may object to reshaping the boundaries, for instance, by pleading for a different underpinning of these boundaries (see Molle 2009).

Second, there are issues of authority, that is, issues of tasks and responsibilities for the new organization (Schlager and Blomquist 2008). Governance scholars warn that large unitary (strong) river basin authorities are just as susceptible to so-called bureaucratic pathologies as any other bureaucracy (cf. Biswas 2004). Schlager and Blomquist (2008) make the point that institution building tends not to follow a pre-established design but in practice can be better described as a patchwork. In composing the patchwork, environmental concerns, for instance, are certainly not dominant. Instead, economies of scale, the costs of coordination, and issues of culture and political identity are said to be most important for those active with the patchwork (Schlager and Blomquist 2008). Interestingly enough, governance scholars suggest that a patchwork of institutions at various overlapping levels may not only be more feasible, but also more desirable from an environmental performance perspective than a unitary river basin authority because of the possibility for reorganizing the patchwork according to the necessary task in a polycentric way. Supporting the idea of institution building as a patchwork, governance scholars, in empirical research, indeed find that the pattern of institution building reflects the importance of governance considerations (politics, institutions) vis-à-vis environmental goals. For instance, Schlager and Blomquist (2008) suggest that most American examples of river basin organizations reflect their current institutional contexts, in the sense that they usually do not have formal decision-making powers and sanctioning authority. Conca et al. (2006) analyzed a worldwide set of 62 transboundary river agreements. They found, among other things, that (1) many agreements do not include all states in a basin and that transboundary agreements are concentrated in basins with a tradition of cooperation; (2) that the content of such agreements depends on power relations between the signatories, with the agreements stressing principles that are advantageous to hegemonic states (Conca et al. 2006, for this summary we built on Huitema et al. 2009). Such findings suggest that in terms of institutional change theory (see, e.g., Thelen 2004) river basin organizations are normally perhaps layered on top of existing institutions, rather than displacing them.

Third, governance scholars draw attention to the fact that after founding a river basin organization, it becomes necessary to formulate decision-making arrangements. In this respect they can opt for two basic choices: the consensus model or elite decision making. Consensus decision making runs the risk of gridlock, whereas elite decision making may result, among other things, in the oppression of minorities (Schlager and Blomquist 2008) or in nonimplementation of decisions when influential stakeholders have not been involved (cf. Ridder et al. 2005). In practice, decision-making arrangements are a mixture of these two basic options, which are perhaps at the extremes of a spectrum. This point connects to an emerging discussion in the wider governance literature. Although many suggest that the image of a neatly ordered and organized government of yesteryear is probably as much fiction as reality, most authors do seem to suggest that the shifts in governance we have seen in the past decades have led to a fundamentally new situation. Hajer (2003) has suggested the term "institutional void," which refers to a situation wherein multiple organizations bear responsibility for (parts of) public problems, and wherein their interrelationships have not been prescribed from a central viewpoint, and so everyone is responsible but at the same time no one is responsible for the whole. Skelcher (2005) suggests that the foundation of the many new organizations that now exist alongside the traditional multipurpose government layers (our previous shifts in governance) have diminished the sovereignty of government. He observes how certain norms of democratic decision making (representation, transparency, and accountability) are much less relevant for the new players in the governance arena, and how this could pose a threat to the functioning of democracy. Thus issues related to the institutional design of such new organizations, including RBOs, gather prominence and that is exactly what we will be concerned with in this special feature.

\section{THE DESIGN OF RIVER BASIN ORGANIZATIONS}

As indicated, it is possible to associate river basin organizations with several different shifts in governance, but it is not immediately clear what is actually being advocated when river basin organizations are being called for. We borrow from Elinor Ostrom's framework for institutional analysis to study the way river basin organizations have been shaped. Ostrom's work is mostly associated with the management of common pool resources, and she is often seen as an advocate of community based management of (small-scale) natural resources. Our reading of Ostrom's work is that she has indeed called for greater attention for a so-called third solution for environmental problems next to the state and the market. However, one other important message she brought is related to the importance of institutions and institutional design on the one hand and the importance of nuance in discussing the difference between various institutional designs on the other (see especially the earlier work in Kiser and Ostrom 1982). With her colleagues, Ostrom helpfully clarified that institutions are actually nested sets of rules. Some rules are merely operational and concern day to day decisions, but others are much more fundamental for the actors who work with these rules and might have a constitutional character. Taken as a bundle (an institutional arrangement), sets of rules create a so-called action situation that influences the actions that actors can take ${ }^{[1]}$. Ostrom has suggested that different types of rules exist, and that an analysis of institutional arrangements should take each of these types into account. Ostrom introduced a rule typology consisting of seven types of rules. Comments by others (see, e.g., Hupe 1990, Heilman 1992, Sabatier 1992) suggest that several of these types are overlapping and that certain types of rules alone can carry the analysis. Taking their experience to heart, we posit that five types of rules are particularly relevant for analyzing institutional arrangements ${ }^{[2]}$ : 
1. Authority rules. These prescribe which positions can take which actions, how actions are ordered, processed, and terminated, i.e., competencies. These rules imply the creation of positions, e.g., a river basin organization, and identify the scope of the authority, e.g., the organization deals with water quality only, and thus determine which so-called states of the world can be affected and which ones not (Ostrom 1986). The authority of other actors to have a say in the river basin organization's decisions is also likely to have an impact on outcomes. Some river basin organizations are bound to be influenced greatly by the input of certain privileged professional bodies or interest groups, while it is also likely to matter which "degrees of citizen power" (Arnstein 1969) exist in river basin organizations when it comes to (assumedly) ordinary citizens (see also the text on boundary rules below).

2. Aggregation rules. These prescribe formulae for weighing individual choices and calculating collective choices. Aggregation rules relate to tensions between individual interests and ways of determining collective choices when these interests are different. At a low level of abstraction, aggregation rules can stress majority or consensus in certain fora, e.g., in a municipal council, as an appropriate condition for taking a decision. At a somewhat higher level of abstraction, aggregation rules are about the philosophical motivation for the decision. One possible aggregation rule is to arrive at decisions that imply the greatest good for the greatest number of people. In other words, the good decision is the decision that maximizes utility for all (utilitarianism). Even though some may lose a bit because of a certain decision, this may be acceptable if the rest of society greatly benefits. Another aggregation rule could stress justice or equity and thus forms of compensation. In this sense, aggregation rules point to the type of rationality that needs to be realized in the decision process (Diesing 1962).

3. Boundary rules. These set the geographical boundaries around the jurisdiction of the RBO, and the entry and exit conditions for actors. They determine who is in and who is out, and by which conditions. Legal rights to participate, for instance on a water abstraction license or a water management plan are sometimes assigned to anyone, sometimes to all aggrieved parties, or sometimes to a landowner only. What this means is that the number of actors participating in the process is likely to differ with variations in boundary rules, and subsequently different interaction types may occur.

4. Information rules. These establish information channels, state the conditions under which they are open or closed, create an official language of acceptable arguments, and prescribe how evidence is to be processed. The management of water may require various "types" of information such as scientific knowledge, but also local knowledge. Rules can identify which of these types is considered more relevant and where they are to be obtained.

5. Pay-off rules. These prescribe how benefits and costs are to be distributed to participants in positions given their actions and those of others.
We expect that use of Ostrom's rule types to characterize river basin organizations offers opportunities for greater conceptual clarity and analytical precision in analyzing them. We feel this is necessary because the current literature on water governance has produced many typologies of river basin organizations, but shows few signs of convergence.

To illustrate the point we briefly discuss some of typologies that are out there at the moment (in the concluding article of this special feature, Meijerink and Huitema 2017, we critically revisit the added value of our own typology too). Mostert et al. (1999) distinguishes between three models for the organization of water management. Whereas in the hydrological model special purpose organizations for river basin management (river basin authorities) need to be established, in the administrative model water management is realized by multipurpose governments, such as provinces and municipalities. In the third, coordinated model, river basin commissions are established and tasked with coordinating action within a river basin. In the first model we may expect conflicts between the river basin authority and general purpose governments, in the second model other interests may be considered more relevant than river basin management, and in the third model, because the decision making rule is unanimity, we may expect basin policies to reflect the lowest common denominator (Mostert et al. 1999). Quite similarly, Alaerts (1999) distinguished between secretariat type of river basin organizations, authority type of river basin organizations, and a category that Alaerts refers to as "other types." The secretariat type of river basin organizations are primarily involved in policy and planning, typically have a small staff component, and can be compared with the coordination model described earlier. The authority type of river basin commission has substantial executive and infrastructural operational tasks and a large staff component, and matches Mostert et al.'s hydrological model. The other types of river basin organizations are examples of "cooperation procedures between existing regular technical departments, or through dedicated departments within one central organization" (Alaerts 1999:13). Because no new organizations are established, this category resembles Mostert et al.'s administrative model. Whereas Mostert et al. and Alaerts use more or less the same typology of three types of river basin organizations, Hooper (2005) presents a taxonomy of no less than nine types of river basin organizations, which he inductively extracted from a review of existing river basin organizations in different parts of the world. He distinguishes between advisory committees, authorities, associations, commissions, councils, corporations, tribunals, trusts, and federations. There is much overlap between these nine types, which makes the typology less useful for empirical analysis. A final typology that we will discuss here is the one suggested by Molle et al. (2007). They distinguish between basin authorities, basin commissions or committees, coordinating councils, and international river commissions. Basin authorities are defined as "autonomous executive organizations with extensive mandates for their river basin, undertaking most water-related development and management functions. They are regulator, resource managers, and service provider all in one" (Molle et al. 2007:610). According to Molle et al. (2007) basin commissions or committees focus more on policy setting and planning and often have specific competences such as defining taxation or effluent standards. Coordinating councils are deliberative decision making bodies 
incorporating public and private stakeholders and integrating river basin policies. Finally, international river commissions are set apart as a specific category because more countries are involved in establishing these commissions. A comparison of this typology with those made by Mostert et al. and Alaerts reveals that Mostert et al.'s hydrological model and Alaerts's authority type of river basin organizations cover both Molle et al.'s basin authorities and basin committees, and that Molle et al.'s coordinating councils resemble Mostert et al.'s river basin commissions.

Both the existence of different typologies and the different naming of RBOs can be confusing. Alaerts (1999:13) rightly argues that the names can be misleading. "Agencies with wide ranging executive tasks are sometimes called 'Commissions' or 'Councils', such as the Mexican Water Councils and National Water Commission, or 'Boards', such as the Dutch Water Boards." Therefore, while acknowledging the relevance of the empirically based typologies discussed above, we feel it is time for a new typology that is anchored in Ostrom's work. Here we will work with a typology of river basin organizations that distinguishes between autonomous river basin organizations, agencies, coordinating basin organizations, and partnerships. Autonomous river basin organizations have a constitutionally guaranteed independent position and have their own mechanisms for democratic control. Agencies are river basin organizations that are created by the state to perform a limited number of specialized tasks at arms' length from the government; they are accountable only to (parts of) government. Coordinating river basin organizations are collaborations of the founding government partners and respond to them. Partnerships are bottom-up initiated governance arrangements that are accountable to their participants, which include civil society organizations. Table 1 presents this typology of RBOs and the accompanying institutional design features, or rule settings.

The typology we propose contains a set of ideal types in the Weberian sense, which means that the types are theoretical and pure concepts that will not often be found in reality. To see the types differently would mean a denial of Ostrom's main point, that institutional designs vary in many possible respects and that most of the differences do matter. However, we do believe that scientific analysis cannot occur without a certain level of simplification, and that our typology might occupy fertile territory and a middle ground between treating all river basin organizations the same on the one hand, and a full blown application of Ostrom's insights on institutional complexity, which would lead to an unmanageable number of types. We find Ostrom's typology useful to color in these types, but do not completely follow her contention that any small variation in a rule creates a whole new type of institution. Instead, we will regard those variations as a deviation from the ideal type.

One of the goals with this special feature is to see whether the typology can indeed be applied to real world examples of river basin organizations; all contributors have been asked to apply it to a case study with which they are familiar. But our aims go further as already suggested by our central research questions. Like Schlager and Blomquist (2008) we feel more attention should be paid to the political aspect of institution building and bricolage. Schlager and Blomquist (2008) point out that the debate about water governance in general, and about river basin organizations in particular, is currently technocratic in nature. River basin organizations are often propagated as an alternative to existing institutions, that are considered to be too fragmented, too much driven by other concerns than water management, lacking in expertise, and incapable of necessary action by politics. Often an implicit assumption is made that these existing institutions can simply be displaced (Thelen 2004) with new ones such as RBOs, which then supposedly bring order and rationality to water governance. Schlager and Blomquist (2008) make several important points in connection with this. They suggest that replacing existing institutional arrangements with river basin organizations has important implications for the nature of public decision making (in line with our discussion of shifts in governance, and comments by Cook et al. [2016] in this special feature on the meaning of the bioregion in reality). Moreover, they suggest that open debate about water governance, stimulated by various diverging organizational perspectives, is necessary in these times of rapid change, whereas letting one organization control water management issues could lead to lock-in effects. Their central thesis is that "watershed politics" simply cannot be avoided, even in a system designed to evade it, and that politicking is simply the way things get done (Schlager and Blomquist 2008:195). Our special feature takes these notions further by asking questions about the effects that politics has on the feasibility and institutional design of river basin organizations; in shedding light on these aspects we contribute to a better informed debate in situations where river basin organizations are considered as an option for improving the governance regime.

\section{THE POLITICS OF DESIGN}

As told by Molle, the history of river basin organizations suggests that since what could be called the discovery of the river basin and the invention of the river basin organization in Western thinking (the Chinese were much earlier he claims), the concept has been "used and appropriated by various constituencies to reorder configurations of power" (2009:485). The point here is that proposals to introduce river basin organizations tend to come from parties who are motivated to change existing institutions and reorder powers in decision making so as to better fit with their subjective purposes. This insight is not uncontroversial, because many advocates of river basin organizations see their ideas as politically neutral and based on objective evidence, suggesting that river basin organizations are more effective, efficient, etc. Our contention is that such neutrality does not exist in reality. Indeed, suggesting that river basin organizations will bring improvement of sorts in comparison with the existing situation, requires a normative position on what would constitute such improvement (an improvement from which angle, for whom?). Terms like effectiveness and efficiency suggest neutrality, but applying them actually requires the expression of goals so that it becomes possible to express in which respect an organization is effective and efficient. Indeed, the history of the discourse on river basin organizations (Molle 2009) shows that these organizations have been put forward to accomplish quite a variegating set of goals. Associated with utopian ideas of the late 19th century, the concept was associated with notions of full control of the hydrological regime and multipurpose dam construction from roughly the 1930s until the 1970s, then partly faded and was revived to address water-quality problems, before 
Table 1. Typology of river basin organizations (RBOs) used in our study.

\begin{tabular}{|c|c|}
\hline Types of RBOs & Typical institutional design features \\
\hline Autonomous & $\begin{array}{l}\text { Authority rules stipulate the independent position of the organization vis-à-vis other government organizations. Specify, which aspects of the } \\
\text { water cycle are exclusively controlled by the organization; } \\
\text { Aggregation rules. The organization is in full control over the issues within its jurisdiction. In certain cases, control over the decisions of the } \\
\text { organization may rest with an elected body, in others it will rest with an appointed and independent leadership. Natural science, engineering, } \\
\text { and economics play dominant roles in the decisions of the organization (rational decision making); technical quality of its work is of the } \\
\text { highest importance to the organization. The organization may have veto power over decisions by other government bodies that affect water; } \\
\text { Boundary rules. The geographical boundaries of the organization's jurisdiction will be based on the (perceived) boundaries of the river basin. } \\
\text { The staff working at the organization mainly consists of experts in the natural sciences or in engineering. In some cases the political leadership } \\
\text { may be elected freely. The organization is likely to have established procedures for involving (certain) stakeholders and ordinary citizens in its } \\
\text { decisions and sees this as a way to build a constituency; }\end{array}$ \\
\hline
\end{tabular}

Information rules. Arguments from the natural sciences, engineering, and from economics are valued very highly. The assumption is that the body has the most relevant expertise on water, and tries to communicate this to other bodies, whose agenda is less water focused. Accountability for decisions rests with the appointed or elected leadership;

Pay-off rules. The organization has its own source of income (for example, has its own tax base); the rules specify which groups contribute to the income of the organization; these rules may have several bases, including the "polluter pays" principle. Spending is broadly related to "water purposes" and payment of taxes will in some cases be related to having a say in the management of the organization.

Agency Authority rules stipulate a mandate that the organization derives from another body (for example, a ministry or a set of ministries). The organization has a specific and limited mandate that orientates its mission; this can be economic development related, but also more focused on ecological goals. Although the organization can work relatively independently and its actions will not continuously be watched, if performance is not satisfactory the founding organization can discontinue the river basin organization. The organization is relatively free to seek out ways of achieving its goals;

Aggregation rules. The organization has attained delegated control over one issue, but is likely to have little leverage over organizations that have similar or related tasks, and coordination mechanisms might be lacking. Control over the decisions of the organization rests with an appointed leadership, which depends on fulfilment of that mission for its continuation. Natural science, engineering and economics play dominant roles in the decisions of the organization (rational decision making), but cost-effectiveness is the main guiding principle; Boundary rules. The geographical boundaries of the organization's jurisdiction will be derived from the government that establishes it. The staff working at the organization mainly consists of experts in the natural sciences or in engineering. The organization has few legal obligations when it comes to involving stakeholders and ordinary citizens in its decision processes, but it may opt to organize stakeholder processes in support of attempts to attain its goals;

Information rules. The organization has a duty to report to its founding organization and this line of communication is the most important one. The organization must view its tasks in a narrow way, and only information that is relevant to its task is collected and considered. In debates about its decisions, cost-effectiveness arguments play a major role, although engineering and natural science arguments are also weighted. The agency sees members of the public as customers rather than citizens and approaches them in this fashion; Pay-off rules. The organization has a set budget, provided by the founding organization to achieve goals that are stipulated in a specific way. There may be rewards for (some) staff members of the organization if the stipulated targets are being met. Such targets may include "customer satisfaction."

Coordinating Authority rules. The organization has no authorities of its own, but it has been founded as a facilitator of coordination between organizations that do have responsibilities in the field of water management. These bodies need to consent to the existence of the coordinating body and their agreement will delineate the responsibilities that the coordinating basin organization can take up. In most cases this will include a research and plan function. If the organization performs well in the eyes of its founders, the tasks may be expanded;

Aggregation rules. The coordinating river basin is founded to better plan policy making, to avoid counterproductive measures by the various founding bodies and to stimulate synergy. Because the river basin organization has multiple founders, diverging interests are present; the founding organizations will have required decision making either by consensus or by large majorities (for example two-thirds of the required votes);

Boundary rules. The coordinating river basin organization is likely to include organizations that are orientated toward very different geographical scales, but the organizations involved cannot cross the jurisdictional boundaries of their combined territories. Because the organization is fundamentally about administrative rationality (see under "Aggregation rules"), only government bodies participate in the basin organization; there might be contacts with certain stakeholders, but the general public is not involved in decisions;

Information rules. The coordinating river basin organization does its own research, which generates information about potentially conflicting measures or creates a larger, cross-jurisdictional perspective on problems and issues. To achieve good levels of coordination, the participating organizations need a safe environment in which they can resolve their conflicts without too many onlookers. Access to information about what is being discussed will therefore be restricted in many cases;

Pay-off rules. All participants contribute to the functioning of the coordinating basin organization, but keep most of their own budget.

Partnership Authority rules. The organization is a bottom-up initiative and has control over a resource that is commonly owned or controlled by the partners. The partnership has a conservation or a sustainable-use purpose, and controls use;

Aggregation rules. Deliberation and consultation between the partners are key; decisions are made on the basis of consensus;

Boundary rules. Joining the partnership is on a voluntary basis. Social control within the partnership implies, however, that membership does imply a set of obligations. As such social control is so essential for the functioning of partnerships, most operate on the local or regional level, which is the level where participants can know each other;

Information rules. Partnerships put the concerns of the participants first. Local knowledge and local memory guides decisions, but not to the complete exclusion of scientific knowledge, which might also be available. The key point is that such information is processed through the prism of the interests of the partners. Partnerships are under no obligation to share the information they have with those outside the partnership;

Pay-off rules. All partners involved are likely to have a direct stake in the decision process and they will seek decisions that protect the interests of those involved. In some cases such decisions may entail costs for nonmembers, but such costs are considered less relevant. 
re-emerging in the 1990s as the cornerstone of IWRM, enriched and blended with watershed- and ecosystem-management approaches.

RBOs have thus been proposed to further holistic economic development and poverty alleviation, to serve agriculture and power generation, but also to further ecological goals. In all of those cases, the proposal to establish a river basin organization is thus not neutral at all, as certain goals would be elevated over others when the proposals are adopted. Moreover, the history of river basin organizations shows that discussions about river basin organizations are not only inspired by what is substantively best, but are indeed also about decision power (power is both the net and the fish, so to speak). In discussions about the reorganization of the state in postrevolutionary France for instance, "[the] concept was captured by political interests and served as a weapon against centralization, as inherited from the Revolution, and was supported by the land-owning aristocracy and by monarchists/ conservatives who sought to re-establish the pre-eminence of the local" (Molle 2009:486). Perhaps better reflecting currently ongoing discussions, Molle (2009:491) also argued the following:

The Ministries of Environment have often invested the river basins as a crucial scale for grounding their legitimacy and assuring their role among pre-existing layers of the administration for which, in turn, RBOs have become sites where decision-making power over financial resources and investments might potentially be relocated at their expense.

On this matter, the Global Water Partnership and the International Network of Basin Organizations (INBO), both of which have established regional branches, tend to favor the establishment of "powerful" or "strong" river basin organizations (Huitema et al. 2009, Molle 2009). For instance, the World Resources Institute (see Cassar 2003:159) states:

[T] he levels of authority that governments grant to RBOs are obviously critical to their abilities to manage their respective basins. The most successful RBOs have strong bases of support among basin governments, and high levels of authority through formal instruments like legislation.

In terms of Ostrom's rule typology, the expectation is apparently that basin governments are especially relevant constituents for river basin organizations (boundary rule), and that river basin organizations should especially be equipped with the power to regulate (authority rules). But we know from the literature on institutional dynamics that creating strong river basin organizations requires the displacement of existing institutions, and that this usually does not occur without resistance. Indeed, the "incumbent authorities," general purpose organizations, such as regions, provinces, and municipalities, often have an interest in curtailing the authority of RBOs because any increase in such authority would come at the expense of their own power. Thelen (2004) suggests that institutional change therefore often takes on a different character than proponents of a wholesale makeover envision. Rather than full-blown displacement, she and others suggest that more common patterns of institutional design are "layering" or "conversion." Layering assumes that a new institution, such as a river basin organization, will simply be added as a new layer to an existing regime without replacing it, whereas conversion is a process where existing institutions reinvent themselves and start taking up tasks that they did not perform previously, thereby perhaps eliminating the need for a new institution. The politics of river basin organizations do not therefore only pertain to the actual design of the basin organization, but also to the redesign of other organizations. As a consequence, grand designs and dreams of institutional engineering can dissolve in practice.

However, we should be careful not to always equate the push for the foundation of river basin organizations only with "strong" river basin organizations, even if these are often preferred in the global water management discourse. Molle (2009:491) suggests that more recently collaborative approaches at the watershed level have risen to prominence, for example in the United States:

The watershed is becoming a central feature of new philosophies or strands of activism like bio-regionalism that emphasizes civic responsibility and ecological stewardship [...] and is concerned with developing patterns of governance that befit natural units defined on ecological and community grounds. [....] As a result, the river basin-level, traditionally invested by state bureaucracies, is challenged [...] by the proliferation of watershed oriented groups that emphasize the principle of subsidiarity and signal the fragmentation of the basin approach (compare Lach and Calvert 2014).

River basin organizations are often the locus of conflicts between environmental and economic interests, such as agriculture and industry. Where the former aim to expand the scope of decision making to ecological and environmental issues, the latter often try to limit the scope of decision making to water availability for economic purposes only. Other conflicts may be about the information and aggregation rules, with some arguing open decision processes, while others are more inclined to keep information in closed circles, some suggest decisions should be mainly based on expert knowledge, and others favor democratic deliberation involving lay knowledge.

Discussions may, however, entail any other design choice and rule. More empirical research is needed to learn more about the main controversies in designing RBOs, and the key actors and coalitions involved. As stated, we proceed on the premise that institutional design choices are political in nature. Such choices define the authority of a river basin organization, the decision making rules, or the penalties for those who fail to live up to agreements made. Thus, if there is a debate about introducing basin organizations, or altering the existing organizations, we consider it likely that parties involved in water resources management and planning will try to influence the institutional design of RBOs in a way that serves their interests best. In this vein, decision making on the architecture of RBOs can be conceptualized as a process of strategic interaction in which actors with diverging ideas about the preferred architecture try to gain support for their ideas. Such actors have diverging preferences for various institutional designs. They may have an interest in either limiting or expanding the authority of a river basin organization, in consensus or majority decision making, in the inclusion or exclusion of specific parties, and so on. 
How do we expect the political discussion on design to unfold? It will be clear by now that we do not expect such discussions to be resolved by convincing arguments alone (be they scientific or otherwise in nature). Seeing this as a political game means we need to pay attention to the actions of proponents and opponents of river basin organizations, and the different possible varieties of such organizations. Like Thelen (2004) and Mahoney and Thelen (2010) we assume a high degree of agency, that is, deliberate action by those involved in the discussion. Unlike them, we are not so much interested in labeling proponents of institutional change (they use the terms "subversives," "parasitic symbionts," and "insurrectionaries," depending on the level of change the players want to achieve; see Mahoney and Thelen 2010). Instead, we are more interested in the way in which proponents and opponents create and use opportunities to push their case (compare Huitema and Meijerink 2009). Disasters, such as floods or periods of severe drought, are important windows of opportunity, which parties may exploit to launch proposals for changing the institutional design of RBOs. They may try to enlarge their scope (for instance by the inclusion of water quantity issues in their mandate if they were previously not included), to give them more authority or they may question their performance at all. As we have learned from previous research on the roles and strategies of policy entrepreneurs, framing and narrative strategies are particularly relevant here (Meijerink and Huitema 2010). In the context of this research the relevant questions then are which narrative about the causes of the disaster and possible remedies becomes dominant, and more specifically, whether RBOs are presented as a means to prevent new disasters. Political windows, such as change of government or regime, may offer opportunities for establishing, abolishing, or changing river basin organizations as well because political parties may have different ideas on the authority and other characteristics of river basin organizations. Finally, parties may try to gain support for their proposals in the multiple venues that are present in most modern societies. If they do not succeed in gaining support for a particular reform proposal in one venue, they may try to gain support elsewhere by shifting attention and action to another forum. Because national, regional, and local governments and different ministries may have different ideas about the necessity or ideal institutional design of river basin organizations, they may be more or less receptive to particular reform proposals. It has been suggested that the game between proponents and opponents of RBOS has a different flavor in various countries. Molle (2009:492), pointing to the differences between the developed and the developing world, argues the following:

In the early years of the $20^{\text {th }}$ century, river basin planning and management were associated with centralism and state-dominated large-scale infrastructural development typical of the 'hydraulic mission', this is still largely the case in developing countries, with some exceptions. Elsewhere, river basin authorities have tended to gradually morph into coordinating agencies and had to reconfigure themselves in order to accommodate local scales and processes, and the diversity of stakeholders and interests.

We expect to encounter such differences in this feature well.

\section{EVALUATING RIVER BASIN ORGANIZATIONS}

Part of the political game surrounding the foundation and design of river basin organizations relates to the purposes they would serve and the criteria that should eventually be used to evaluate success or failure. The various parties involved in the discussions on the design of river basin organizations, including different ministries, levels of governments, and a wide range of interest groups, all have different demands and will highlight diverging goals for water resources management, hence they tend to use different evaluation criteria. There is a host of goals that RBOs could be asked to take up, and consequently quite a range of evaluation criteria that these parties may use. These include environmental, agricultural, or industrial objectives, but also questions of fit into the overall governance regime. Here, we want to limit our evaluation to a more generic set of criteria that may be used to evaluate shifts in governance. The question that we are interested in is his: to what extent does the RBO enhance coordination, accountability, legitimacy, and environmental effectiveness? In the following, we will discuss these evaluation criteria and their relevance for the types of RBOs which we have distinguished previously.

We interpret coordination as pertaining to public decision and policy making. The discourse about governance and shifts in governance came up in an era when government bureaucracies had inflated greatly. Proponents of smaller government successfully argued that the real issue was no longer market failure, but government failure. Government failure was seen specifically in the impossibility to coordinate the multiple government interventions and policies through instruments like rational planning. It was relatively easy to point out the existence of contradictory policies, for instance in the field of environmental policy where a lot of policy activity was aimed at undoing the policies of competing ministries such as agriculture. As the debate on governance went on to become a debate about the existence of policy networks and multilevel governance, it became increasingly clear that coordination also has a so-called vertical dimension, that is, that policies from different jurisdictional levels also need coordination, which is provided by planning in government bureaucracies. But the belief in planning has waned considerably since the $1970 \mathrm{~s}$. Hence there was a need for other mechanisms to achieve coordination. As for the government tasks that were not privatized or hived-off, the trust in planning was replaced with a belief in self-organizing networks that would spontaneously create order out of chaos. Public policies, or their governance pendant of voluntary agreements, were expected to emerge from a process in which governments were an equal partner to other parties (comanagement), and the government task was one of facilitation rather than regulation (for instance through seed money for water user associations). Obviously, the ensuing process of consultations and dialogue does require effort and time, and one may wonder whether the coordination challenge may have gotten all that smaller. In fact, in many cases where authors plead for strong river basin organizations, their ambition is to do away with a lot of red tape and coordination and simplify or streamline decision making by concentrating power in the hand of one organization. This thinking is probably most prominent among those pleading for autonomous or agency type of basin organizations. Regardless of which type of basin organization is founded however, water 
managers will always remain (highly) dependent on the cooperation of other policy sectors and other actors. Although from a water management perspective, the focus on hydrological units is a logical one, the key to solving water management issues mostly is with organizations who work on very different geographical and jurisdictional scales. The dilemma thus is that one may develop strong and powerful basin organizations, which enhance spatial fit, but that these organizations remain dependent on others for realizing their objectives. The issue has been analyzed from the perspective of the term institutional interplay. "Institutional interplay refers to boundary problems of a different kind. The boundaries at stake here relate not to physical boundaries, but to political responsibilities and social spheres of influence" according to Moss (2004:87). The establishment of large basin organizations with many competencies means that just another jurisdiction is added, that institutional complexity is increased, and that it may become more difficult to realize the necessary interplay between all relevant jurisdictions (at various levels of government). So the question remains: which type of basin organization then is better at avoiding contradictory policies, redundant organizations, conflicts about geographical and jurisdictional boundaries, etc.? Which one is better able to enhance synergies between water management and other policy fields? Are these the strong forms of river basin organizations, or rather the weak type such as partnerships and coordinating basin organizations?

Accountability is a concept that is increasingly discussed in the debate on the shifts in governance that have taken place in the past decades (see, e.g., Bovens 2007 and 2010 for a discussion of the relevance of the concept in the setting of the European Union; and Dryzek and Stevenson 2011, or Biermann and Gupta 2011, for a discussion of the relevance at the global level). In water management, the term accountability is heard less often. Water management is regarded by many as an exclusively technical challenge, which is apolitical in character and amendable to finding the best solutions through engineering. This view has permeated the recent history of water management in many countries and it has had implications for the way decisions have been set up. If water management is a purely technical challenge, access to decision processes should be limited to those who have technical expertise. If it really is an apolitical challenge, there is little need for fora of contestation. Indeed, the models engineers and other natural science disciplines use are then probably seen as objective representations of the truth and there is little sense in arguing about their underlying assumptions and philosophies. In such a situation, demands for accountability can remain limited. However, as stated, we interpret the foundation of river basin organizations as a shift in governance, bound to result in political contestation. And we have already demonstrated how authors such as Skelcher $(2000,2005,2006)$ develop critical questions about the various shifts in governance that have taken place around the globe and what these imply for fulfilment of the criterion of accountability. Skelcher's sombre reading is that shifts in governance have implied greater fragmentation (a spaghetti of responsibilities) and subsequently a lack of clarity in decision structures. He also predicts a waning of centripetal forces in the system, which means that collective decision making becomes problematic. It becomes murky to understand who is responsible for what, and when there are problems, all governing bodies involved have an incentive to withdraw from sight and to claim to not be responsible.

But backing up a little, we should probably be clear on what the term accountability means. According to Bovens (2007), the term has Anglo-Norman roots and the word derives from the bookkeeping (accounting) that property holders had to do for the Norman kings. However, according to Bovens (2007), in the English language the term has transcended the realm of financial administration. It currently refers to reporting by governors to their polity rather than the opposite, and conveys the promise of fair and equitable governance. It can therefore be defined as "a relationship between an actor and a forum, in which the actor has the obligation to explain and justify his or her conduct, the forum can pass questions and can pass judgement, and the actor may face consequences" (Bovens 2007:450). Bovens (2007 and 2010) has suggested that the concept can be used in a broad and in a narrow sense. When used in the broader sense it is an evaluative concept, and when applied in the narrower sense it refers to the mechanisms for account giving. Here we are obviously more interested in the accountability as an evaluative concept. From that perspective it is important to discern between three rationales for accountability, because accountability can first be concerned with the democratic means to monitor and control government conduct, second with the prevention of power concentrations, and third with the enhancement of the learning capacity of public administration (Bovens 2007:462-463). Here the logic we will follow is that of democratic control. The key questions in such a line of reasoning concern the degree to which institutions have been effectively linked to the democratic chain of delegation, which means that questions need to be asked about the degree to which democratically legitimized bodies (or the polity) can monitor and evaluate organizational behavior, and enable such bodies to influence organizational behavior so that it is consistent with their preferences. Bovens (2007:462) suggests that assessments of the accountability provided by agencies or sectors are often a matter of degree and "follow the logic of more-orless." This is because assessments can result in the conclusion that there is a lack of accountability (an accountability deficit), but there can also be too much accountability, especially when a "dysfunctional accumulation of a range of accountability mechanisms" (Bovens 2007:462) has come into existence.

If we connect this more precise understanding of the kind of accountability that we are after to the debate about river basin organizations, we can conclude that the foundation of river basin organizations (almost irrespective of the type) will indeed affect accountability. However, this can work two ways actually. One possible effect is that the foundation of RBOs contributes to the fragmentation of authority and to what we labeled the spaghetti of responsibilities. Plus, the new organization, the RBO, is likely to be a relatively unknown entity, which, depending on its scale, could actually be physically quite far removed from some of its constituencies. It is, however, also thinkable that the foundation of a river basin organization is a simplification of water management and that the organization makes water management rather more accountable compared with a situation where water management tasks were part of the general public administration. It can therefore not be assumed beforehand that river basin organizations threaten accountability. In addition, the effects on accountability can be uneven. One must not lose sight of the fact 
that transparency and accountability can be very unevenly applied to various parts of the general public. In fact, the problem of collusion suggests that water managers are extremely accountable to one segment of the public (for instance farmers), but not to other constituencies that might be equally relevant. This obviously relativizes the absoluteness of the imperatives of transparency and accountability. What is more, the issue of accountability is different for different types of RBOs. The agencies and coordinating RBOs, which we have defined in Table 1 , are primarily accountable to their constituent government agencies. If these RBOs are given too much freedom in realizing their tasks, accountability may become an issue indeed. On the other hand, a limitation of their discretionary powers may come at the cost of their effectiveness, which suggests that there may be a trade-off between accountability and effectiveness in some cases. For autonomous RBOs the accountability issue is more complicated. On the one hand one may argue that for this type of RBO, accountability is less of an issue because these RBOs do have their own (in)directly elected board. On the other hand, because of the existence of such a board there often is considerable institutional overlap with general purpose governments who also address specific water issues. Although such institutional overlap may contribute positively to the adaptive capacity of the water sector, it may also lead to a situation in which citizens no longer know which organization should be held accountable to specific water policies. Finally, for partnerships, accountability is likely to be about their relationship to the participating parties. Whereas some may judge these partnership arrangements negatively because of poor accountability to the general public, others may emphasize their merits because they offer opportunities for developing new practices of deliberative democracy or because they offer new avenues for influencing water management practices for actors who used to be marginalized.

Legitimacy refers to the public perception of water management. Countries differ in the degree to which the general population is aware of water management activities, but the treatment of water management as merely a technical issue could have a logical correlate in lower public awareness. Once initial investments in large-scale water infrastructure are made, it takes quite some determination to keep their maintenance on the agenda and longterm investment is often an easy political target for budget cuts (see the recent discussion in the United States on the depleted [water] infrastructure). And especially with flood infrastructure, long periods without floods might instil a false sense of security and this in turn may invite risky investment and settlement behavior. Obviously, such periods of low public awareness might be punctuated by extreme weather events such as protracted periods of drought or rain. It can thus be argued that it is important to maintain a certain level of public dialogue on water issues so that water problems stay in the public view and mind. Dialogue implies a bilateral communication process, and much of the writing on public participation in water management suggests that water managers can improve their operations if they use the collective wisdom of the crowd (although experts will always remain important). This touches upon various other aspects: using local or lay knowledge might help achieve ecological objectives, improve cost effectiveness, and enhance legitimacy. We will be the last ones to suggest that such legitimacy only depends on dialogue, but one form of legitimacy, known as input legitimacy, will especially benefit from such dialogue because it refers to the way in which institutions effectively deal with the feedback from the wider public. Other forms of legitimacy include output legitimacy and systematic legitimacy, concepts that refer respectively to the delivery of goods and services and the broader feeling of support for the institutional set up. It is difficult to say beforehand which type of RBO contributes most to the legitimacy of water resources management because this strongly depends on the way in which a specific RBO involves the general public in developing and/or implementing basin policies. From the perspective of input legitimacy, the partnerships and autonomous RBOs probably do better than the agencies and coordinating committees, but from the perspective of output legitimacy this may well be the other way round. The large variety and number of parties involved in most watershed partnerships in combination with a decision making rule of unanimity, may easily lead to a stalemate or to decisions that reflect the lowest common denominator (Schlager and Blomquist 2008). That is why one hypothesis is that partnerships will often not deliver, and subsequently have a low output legitimacy.

The criterion of environmental effectiveness refers to goal attainment in the realm of ecological issues. As suggested above, most modern day proponents of river basin organizations do expect river basin organizations to take ecological issues more seriously than the existing institutions and hence deliver better performance. But what are these ecological issues and how can we classify them? Certainly since the 1950s and 1960s water pollution has continued to be a staple element in the debate about water management. In many countries, water quality issues that emanated from petrochemical and other previously existing industries (such as textile and paper production) became increasingly controversial when their effects on nature became clear. The impact of agriculture, through water abstraction, through the use of fertilizers and pesticides should also not be overlooked. But there are more issues. The hydrological mission, often hinging on the erection of massive infrastructural constructions, has had (and is having) enormous impacts on the landscape, on the flora and fauna connected to the water system, and the livelihood of countless people living in affected areas. The environmental movement that started in the 1960s has battled against such developments in many countries, often in combination with other civil society groups. And then there is the issue of climate change; although it is often thought of as a global phenomenon, the local effects can differ greatly. Whereas the predictions are that some climate zones will get drier, in others more precipitation can be expected. And even if averages in rainfall and other weather conditions were to remain constant in various regions, the frequency with which extreme weather events (be they droughts or high levels of precipitation) occur is expected to rise. Coupled with a pattern of economic investment and human settlement in vulnerable regions, this has led to increased damage levels in the last decades (for a discussion on the various factors affecting such risks see for instance Bouwer et al. 2007, Bouwer 2010). An obvious correlate of the variable impacts of climate change is the fact that such damages can vary greatly between localities and jurisdictions, including the ones that are upstream and downstream of rivers. River basin organizations are expected to help address such problems by connecting such 
jurisdictions, but also by focusing more squarely than general purpose governments would do on the ecological aspects. But whether such expectations really come true is still an open question (for attempts to answer aspects of it see Dinar et al. 2005 and Schlager and Blomquist 2008). However, from our brief summary of ecological problems that water managers face it already becomes clear that such issues are becoming more rather than less challenging. Climate change cuts through and across jurisdictions, sectors (such as water and energy), and does not stop and start at the boundaries of a river basin. Whether autonomous river basin organizations handle such challenges better than other types, as is often assumed, remains to be seen.

\section{LOOKING AHEAD}

In the rest of special feature the four central questions that guide our analysis - about the design of river basin organizations, their proponents and opponents and their effects on design, the impacts that these organizations have, and whether we can develop recommendations for those engaged in the discussion-will be followed up. The heart of this feature consists of four articles on river basin organizations, each addressing the first three questions. These four articles were embedded in much larger comparison of 11 international case studies (see Huitema and Meijerink 2014), contextualized by an overview of the global discussion on river basin organizations (Jaspers and Gupta 2014). In the concluding article of this special feature, Meijerink and Huitema (2017), we provide a synthesis of the observations from all 11 case studies (thus taking on board insights from the four case studies included in the special feature but also the seven case studies that could not be included). In addition, in the concluding contribution to this feature (Meijerink and Huitema 2017) we draw general conclusions, and address the fourth question posed in this introduction.

It is probably good to offer some explanation on why we are focusing here on river basin organizations within countries and why we subsequently selected the countries that were included here and in our broader project (Huitema and Meijerink 2014). The focus on national discussions on river basin organizations stems from the personal preferences by the editors, but is also related to the fact that basin organizations within country borders are logically a more common and frequent form of organization than the special case of transboundary RBOS, which have in fact attracted a large, perhaps disproportionate, amount of attention already from water governance scholars (for examples, see Beach et al. 2000, Rieu-Clarke 2005, Conca 2006, Molle et al. 2009, Schmeier 2013).

The selection of countries and cases presented in this special feature and the broader comparison presented in Huitema and Meijerink (2014) has not been steered by conceptual considerations as much as one would normally like. In the ideal situation one would select such cases on the basis of either the independent or the dependent variable, and the chances they pose to reject explicit hypotheses surrounding these key variables. The issues we are grappling with cannot be framed so neatly however. Our contribution is first to see whether the new typology of RBOs can be applied to real world cases (this is not a matter of rejecting hypotheses, except perhaps of course that we expected the typology to work). Second, we wish to see how proponents and opponents of RBOs tried to influence RBO design, third, to see whether certain types of RBOs perform better than other types, and finally to derive recommendations. Only for the performance issue one might say that there is a working hypothesis in the literature, which would be that autonomous RBOs will perform better (see the previous discussion on environmental effectiveness), but this hypothesis has certainly also been challenged extensively.

The implication is that the contributions to this feature should be seen largely as inductive empirical studies, and only to a limited degree as focusing on deductive hypothesis testing. Despite that being the case, the special feature makes a contribution to the overall discussion on adaptive governance and water governance more broadly, by better conceptualizing river basin organizations as an example of a bioregional approach, and by asking questions about the politics surrounding the foundation of RBOs (and by implication bioregional organizations). The issue of politics has been treated in the existing literature on RBOs of course, but is often quickly dispatched as a problem, as something irrational in the way of an otherwise brilliant plan and something that should be done away with rather than analyzed more profoundly (exceptions include Schlager and Blomquist 2008). In bringing together multiple country case studies, we hoped to show that politics always play a role in these discussions and simply cannot be treated as the irrational part of the equation. In methodological terms, it could be argued that our collection presents the most different systems approach, which implies that when the relation between two variables (says politics and institutional design) is found across a number of very different systems (or countries) this can be seen as corroboration that the variables are indeed causally related; in fact the more countries are tested for and the greater the differences between them, the greater the confidence in the finding of a connection (Hopkin 2002).

The set of three questions we ask about every country (as indicated the fourth question is reserved for the final article) may seem simple at first, but answering them actually requires quite a bit of in depth knowledge of the case studies. In combination with the fact that we mostly have an inductive and exploratory agenda, this means that in this feature we opted for collaboration with colleagues who intimately knew the case studies they describe beforehand. By collaborating with us, and applying our framework, they were invited to present this knowledge in a way that was fitting with our purpose, and they helped us to explore the questions we asked. We acknowledge that working with authors who are familiar with certain case studies has potential downsides. It might introduce certain biases (some authors may have become attached to "their" case studies) and it could have implied an exclusive focus on parts of the world for which many analyses already exist. We have worked to erase any biases emanating from familiarity with the case study by submitting all papers to peer review (all authors read each other's work and critically commented on previous versions during a meeting in Amsterdam, the Netherlands). It is obviously up to the reader to decide whether these biases were indeed effectively removed, but we believe that to be the case.

Another potential criticism of our case study selection could be related to the fact that the RBOs studied in the various countries do differ quite considerably in geographical scale. This is a consequence of our way of selecting cases (based on the expertise 
of the authors, not on the comparability of the case studies). And to our mind this variation offers mainly advantages from a methodological perspective (see the comment about the most different systems approach) and from a conceptual perspective, because the variation in geographical size does offer an opportunity to see whether certain types of RBOs (like partnerships) are indeed confined to the very local scale, as is often assumed in the literature (perhaps this is another rare example of a testable hypothesis). Before we now turn to the various contributions to this special feature, we briefly introduce the various cases that will be described, by already revealing which type of RBO they represent, and which conclusions we were able to draw about this type of $\mathrm{RBO}$ based on the broader selection of case studies described in Huitema and Meijerink (2014). In this special feature, we will encounter two examples of coordinating type RBOs, specifically the Mackenzie River Basin Board (MRB) in Canada, which is described by Michelle Morris and Rob de Loë (2016), and the Murray-Darling Basin Ministerial Council in Australia and the Basin Community Committee there as described by Andrew Ross and Daniel Connell (2016; they also discuss the Murray-Darling Basin Authority, but this is an agency type of organization). Several common threads weave the stories on coordinating type of RBOs together. In terms of institutional design, these organizations all have an indirect mandate, derived from the organizations that have founded them. This means that the pattern of institution building can usually best be described as layering, meaning that the new institution is just another layer in an already complex setting. Two points become clear about the process of layering, one about bureaucratic politics, and about the relation to more traditional institutions. As for bureaucratic politics, the founding organizations, be they ministries, provinces, or other forms of government, are not in the game wholeheartedly. This means that there are usually organizations that try to limit the amount of resources that the new organizations will obtain (in terms of finances, in terms of information flows, in terms of decision power) either by institutional design, or by not collaborating with the RBOs once they have been founded. As for the relation to more traditional (or indigenous) institutions, it is noteworthy that RBO design often does not fully involve these institutions, or even neglects their existence. Part of the reason for that is that the idea for the foundation of the RBO comes from outside the circles that were managing water before. This is not so much visible in the two case studies included in this special feature, but our broader collection (Huitema and Meijerink 2014) contains cases in developing and transition countries like Afghanistan, Mongolia, and Ukraine, and there, foreign parties such as consultancies from Western countries carry the international thinking on RBOs to these countries, usually accompanied by national allies that stand to gain with the RBO or support the idea intellectually. Such parties enter through windows of opportunity created by various recurring factors, such as the dependency on foreign subsidies, broader societal and political changes, and an active political leadership that supports innovation. The dependency on other parties, but also the fact that the initiative comes from outside traditional water circles, goes a long way to explain the relative weakness of almost all coordinating RBOs described in this special feature and the underlying larger project (Huitema and Meijeirnk 2014) in terms of resources and authority. As a correlate, performance is often judged to be relatively poor by our authors, with in some cases traditional institutions actually needed to help out in terms of coordination in times of crises (which underpins the case for institutional diversity and polycentricism perhaps).

There are examples of agency type RBOs in this special feature, specifically the Breede-Overberg Catchment Management Agency in South Africa, described by Richard Meissner, Nikki Funke, and Karen Nortje (2016), and the Murray-Darling Basin Authority in Australia as discussed by Andrew Ross and Daniel Connell (2016). In our broader set of case studies, we find case studies from the U.S., Germany, and Ukraine too. In each of these countries agencies coexist with coordinating types of RBOs in one way or another. Often agencies take on the role of the implementing branch, under the umbrella of a coordinating organization. It is interesting to observe that some RBOs in this small subset of cases have a relatively narrow mandate, focusing, for instance, on salmon restoration, which fits within our typology, but also that some agency type RBOs turn out to have a much broader mandate. For all agency type of RBOs, the political sensitivity of their establishment and the key importance of having sufficient resources is confirmed. The South African case description (Meissner et al. 2016) details how over the course of 14 years, only two out of 19 projected catchment management agencies (CMAs) were actually founded. This is to do with opponents to the decentralization drive implied in their foundation, but the authors also claim that a lack of resources (funding, capable personnel) is also to blame. In countries like South Africa, the thinking about RBOs appears to be hesitant and evolving. In South Africa CMAs are meant to be very much under the wing of the relevant minister, until they have proven they can function independently (when they become more purely an agency). But given the paucity of actual experience with the CMA model, their performance is actually quite hard to judge.

In this special feature we also present the only example of a partnership type RBO that was included in our broader selection of case studies. Hadrian Cook, David Benson, and Laurence Couldrick (2016) describe the case of the Westcountry Rivers Trust from the Southwest of England. They suggest that the rise of partnership type of basin organizations in the UK should be seen in the light of low trust in the formal system of water governance, which is dominated by agency type organizations. The partnership nature of this RBO is reflected in its focus on consensual decision making, local expertise, holistic approach, and desire to find win-win solutions. In this particular case, the initiators were successful in attracting outside resources (such as from the European Union) and the authors consider its performance to be relatively good.

Having introduced the various guiding questions to the special feature and the following contributions, we gladly invite the reader to read the various case studies included in this special feature for more detail on the nuances of RBO design, and to read the concluding article of this special feature, Meijerink and Huitema (2017), to get a systematic analysis the global comparative study we performed.

${ }^{[1]}$ The action situation is also influenced by natural circumstances and culture, but these are factors that Ostrom has not elaborated upon a lot. 
${ }^{[2]}$ Ostrom has indicated that rules work configurationally. This implies that if the "setting" of one type of rule changes, the total set of rules is affected, and the rules will have a different effect (Ostrom 1986). This insight is profound, but also potentially very disruptive of our possibilities for generalization. Imagine an institutional arrangement wherein 50 positions are specified, each associated with 50 boundary rules, 50 information rules, etc. If it is true that a change in one of these rules affects the entire setting and effectively a new institutional arrangement is created, we would end up with a massive amount of possible institutional configurations, with assumedly all very different outcomes. Such a complex web of options goes beyond the human capacity of analysis and understanding. This is probably why Elinor Ostrom is often associated simply with community-based management, which could mean a range of things if one applied her typology. It is probably also why the impressive work Ostrom has done leads to a set of relatively simple design guidelines (for instance that the enforcement of rules and thus the design of enforcing positions and authorities is important). For us, the conclusion is that the level of sophistication in the analysis is better bounded, and templates or shorthand such as the market or the state do have some value.

Responses to this article can be read online at: http://www.ecologyandsociety.org/issues/responses. $\mathrm{php} / 9409$

\section{Acknowledgments:}

This is a slightly amended version of a text that was previously published as Huitema, D., and S. Meijerink. 2014. The politics of river basin organisations: institutional design choices, coalitions and consequences. Pages 1-37 in D. Huitema and S. Meijerink, editors. The politics of river basin organisations: coalitions, institutional design choices and consequences. Edward Elgar, Cheltenham, UK. The authors wish to thank Edward Elgar Publishing who have kindly given their permission for the reuse of the material. The reader is kindly referred to this publication for more in-depth analysis of RBOs. Certain parts of text in the first two sections have been adapted from Huitema, D., E. Mostert, W. Egas, S. Moellenkamp, C. Pahl-Wostl, and R. Yalcin. 2009. Adaptive water governance: assessing the institutional prescriptions of adaptive (co-)management from a governance perspective and defining a research agenda. Ecology and Society 4(1):26. This special feature follows up on some aspects of the agenda presented in that article, and Dave Huitema gratefully acknowledges the contributions of his coauthors to the thinking presented there.

\section{LITERATURE CITED}

Aberley, D. 1999. Interpreting bioregionalism. Pages 13-42 in M. V. McGinnis, editor. Bioregionalism. Routledge, New York, New York, USA.

Alaerts, G. 1999. Institutions for river basin management. The role of external support Agencies (international donors) in developing cooperative arrangements. World Bank, Washington, D.C., USA.
Arnstein, S. R. 1969. A ladder of citizen participation, Journal of the American Institute of Planners 35:216-224. http://dx.doi. org/10.1080/01944366908977225

Beach, H. L., J. Hamner, J. Hewitt, E. Kaufman, A. Kurki, J. Oppenheimer, and A. Wolf. 2000. Transboundary freshwater dispute resolution. Theory, practice and annotated references. United Nation University Press, Tokyo, Japan.

Biermann, F., and A. Gupta. 2011. Accountability and legitimacy: an analytical challenge for earth system governance. Ecological Economics 70:1854-1855. http://dx.doi.org/10.1016/j. ecolecon.2011.07.017

Biswas, A. K. 2004. Integrated water resources management: a reassessment. Water International 29:398-399. http://dx.doi. org/10.1080/02508060408691794

Bouwer, L. M. 2010. Disasters and climate change: analyses and methods for projecting future losses from extreme weather. Dissertation. VU University Amsterdam, The Netherlands.

Bouwer, L. M., R. P. Crompton, E. Faust, P. Höppe, and R. A. Pielke Jr. 2007. Confronting disaster losses. Science 318:753. http://dx.doi.org/10.1126/science.1149628

Bovens, M. 2007. Analysing and assessing accountability: a conceptual framework. European Law Journal 13(4):447-468. http://dx.doi.org/10.1111/j.1468-0386.2007.00378.x

Bovens, M. 2010. Two concepts of accountability: accountability as a virtue and as a mechanism. West European Politics 33 (5):946-967. http://dx.doi.org/10.1080/01402382.2010.486119

Cassar, A. 2003. Transboundary environmental governance: the ebb and flow of river basin organizations. Pages 158-159 in World resources 2002-2004: decisions for the Earth: balance, voice, and power. World Resources Institute, Washington, D.C., USA. [online] URL: http://www.wri.org/sites/default/files/pdf/wr2002 fullreport. pdf

Conca, K. 2006. Governing water: contentious transnational politics and global institution building. MIT Press, Cambridge Massachusetts, USA.

Conca, K., F. Wu, and C. Mei. 2006. Global regime formation or complex institution building? The principled content of international river agreements. International Studies Quarterly 50:263-285. http://dx.doi.org/10.1111/j.1468-2478.2006.00402.x

Cook, H., D. Benson, and L. Couldrick. 2016. Partnering for bioregionalism in England: a case study of the Westcountry Rivers Trust. Ecology and Society 21(2):38. http://dx.doi. org/10.5751/ES-08504-210238

Davis, F. W., C. Costello, and D. Stoms. 2006. Efficient conservation in a utility-maximization framework. Ecology and Society 11(1):33. http://dx.doi.org/10.5751/es-01591-110133

Desmet, P., and R. Cowling. 2004. Using the species-area relationship to set baseline targets for conservation. Ecology and Society 9(2):11. http://dx.doi.org/10.5751/es-01206-090211

Diesing, P. 1962. Reason in society. Five types of decisions and their social conditions. University of Illinois Press, Urbana, Illinois, USA. 
Dinar, A., K. Kemper, W. A. Blomquist, M. Diez, G. Sine, and W. Frau. 2005. Decentralization of river basin management: a global analysis. Policy Research Working Paper 3637. World Bank, Washington, D.C., USA. http://dx.doi.org/10.2139/ $\underline{\operatorname{ssrn} .757227}$

Donovan, S. M., C. Looney, T. Hanson, Y. Sánchez de León, J. Wulfhorst, S. D. Eigenbrode, M. Jennings, J. Johnson-Maynard, and N. A. Bosque Pérez. 2009. Reconciling social and biological needs in an endangered ecosystem: the Palouse as a model for bioregional planning. Ecology and Society 14(1):9. http://dx.doi. org/10.5751/es-02736-140109

Dryzek, J. S., and H. Stevenson. 2011. Global democracy and earth system governance. Ecological Economics 70:1865-1874. http://dx.doi.org/10.1016/j.ecolecon.2011.01.021

Gupta, J. 2009. Driving forces in global fresh water governance. Pages 37-57 in D. Huitema and S. Meijerink, editors. Water policy entrepreneurs: a research companion to water transitions around the globe. Edward Elgar, Cheltenham, UK. http://dx.doi. org/10.4337/9781849803366.00012

Hajer, M. 2003. Policy without polity? Policy analysis and the institutional void. Policy Sciences 36:175-195. http://dx.doi. org/10.1023/A:1024834510939

Heilman, J. G. 1992. Some thoughts on a rule based conceptual framework for institutional analysis in water policy research. Pages 59-83 in H. Th. A. Bressers and L. J. O'Toole, editors. International comparative policy research: preparing a four country study on water quality management. CSTM, Enschede, The Netherlands.

Held, D. 2006. Models of democracy. Polity, Cambridge, UK.

Hopkin, J. 2002. Comparative methods. Pages 249-270 in D. Marsh and G. Stoker, editors. Theory and methods in political science. Second edition. Palgrave McMillan, New York, New York, USA.

Hooper, B. 2005. Integrated river basin governance. Learning from international experience. IWA, London, UK.

Huitema, D., and S. Meijerink, editors. 2009. Water policy entrepreneurs: a research companion to water transitions around the globe. Edward Elgar, Cheltenham, UK. http://dx.doi. org/10.4337/9781849803366

Huitema, D., and S. Meijerink. 2014. The politics of river basin organizations: institutional design choices, coalitions and consequences. Pages 1-37 in D. Huitema and S. Meijerink, editors. The politics of river basin organizations: coalitions, institutional design choices and consequences. Edward Elgar, Cheltenham, UK.

Huitema, D., E. Mostert, W. Egas, S. Moellenkamp, C. PahlWostl, and R. Yalcin. 2009. Adaptive water governance: assessing the institutional prescriptions of adaptive (co-)management from a governance perspective and defining a research agenda. Ecology and Society 14(1):26. http://dx.doi.org/10.5751/ES-02827-140126

Hupe, P. 1990. Intenties en interacties; over postmoderne en andere instrumenten van overheidssturing. Pages 223-234 in J. A. M. Hufen and A. B. Ringeling, editors. Beleidsnetwerken; overheids-, semi-overheids-, en particuliere organisaties in wisselwerking. VUGA, Den Haag, The Netherlands.
Jaspers, F., and J. Gupta. 2014. Global water governance and river basin organizations. Pages 38-66 in D. Huitema and S. Meijerink, editors. The politics of river basin organizations: coalitions, institutional design choices and consequences. Edward Elgar, Cheltenham, UK. http://dx.doi.org/10.4337/9781782549222.00007

Kiser, L. L., and E. Ostrom. 1982. The three worlds of action. A meta-theoretical synthesis of institutional approaches. Pages 179-222 in E. Ostrom, editor. Strategies of political inquiry. SAGE, Thousand Oaks, California, USA.

Lach, D., and D. Calvert. 2014. Designing an agency to manage a wicked water problem: the Oregon Watershed Enhancement Board. Pages 96-118 in D. Huitema and S. Meijerink, editors. The politics of river basin organizations: coalitions, institutional design choices and consequences. Edward Elgar, Cheltenham, UK. http:// dx.doi.org/10.4337/9781782549222.00009

Lundqvist, J., U. Lohm, and M. Falkenmark. 1985. Strategies for river basin management: environmental integration of land and water in a river basin. Reidel, Dordrecht, The Netherlands. http:// dx.doi.org/10.1007/978-94-009-5458-8

Mahoney, J., and K. Thelen, editors. 2010. A theory of gradual institutional change. Pages 1-37 in J. Mahoney and K. Thelen, editors. Explaining institutional change: ambiguity, agency, and power. Cambridge University Press, Cambridge, UK. http://dx. doi.org/10.1017/cbo9780511806414.003

McGinnis, M. V., editor. 1999. Bioregionalism. Routledge, New York, New York, USA.

Meijerink, S., and D. Huitema. 2010. Policy entrepreneurs and change strategies: lessons from sixteen case studies of water transitions around the globe. Ecology and Society 15(2):21. http:// dx.doi.org/10.5751/es-03509-150221

Meijerink, S., and D. Huitema. 2017. The institutional design, politics, and effects of a bioregional approach: observations and lessons from 11 case studies of river basin organizations. Ecology and Society 22(2):41. http://dx.doi.org/10.5751/ES-09388-220241

Meissner, R., N. Funke, and K. Nortje. 2016. The politics of establishing catchment management agencies in South Africa: the case of the Breede-Overberg Catchment Management Agency. Ecology and Society 21(3):26. http://dx.doi.org/10.5751/ ES-08417-210326

Mitchell, B. 1990. Integrated water management: international experiences and perspectives. Belhaven, London, UK.

Molle, F. 2008. Nirvana concepts, narratives and policy models: insights from the water sector. Water Alternatives 1(1):131-156.

Molle, F. 2009. River-basin planning and management: the social life of a concept. Geoforum 40(3):484-494. http://dx.doi. org/10.1016/j.geoforum.2009.03.004

Molle, F., T. Foran, M. Käkönen, editors. 2009. Contested waterscapes in the Mekong region. Hydropower, livelihoods and governance. Earthscan, London, UK.

Molle, F., and P. Wester, editors. 2009. River basin trajectories: societies, environments and development. CABI, Wallingford, UK. http://dx.doi.org/10.1079/9781845935382.0000

Molle, F., P. Wester, and P. Hirsch. 2007. River basin development and management. Pages 585-624 in D. Molden, editor. Water for 
food, water for life: a comprehensive assessment of water management in agriculture. Earthscan, London, UK.

Morris, M., and R. C. De Loë. 2016. Cooperative and adaptive transboundary water governance in Canada's Mackenzie River Basin: status and prospects. Ecology and Society 21(1):26. http:// dx.doi.org/10.5751/ES-08301-210126

Moss, T. 2004. The governance of land use in river basins: prospects for overcoming problems of institutional interplay with the EU Water Framework Directive. Land Use Policy 21(1):85-94. http://dx.doi.org/10.1016/j.landusepol.2003.10.001

Mostert, E., editor. 2000. River basin management. Proceedings of the International Workshop on River Basin Management, 27-29 October 1999, The Hague, the Netherlands. UNESCO, Paris, France.

Mostert, E., E. van Beek, N. W. M. Bouman, E. Hey, H. H. G. Savenije, and W. A. H. Thissen. 1999. River basin management and planning. Pages 24-55 in E. Mostert, editor. Proceedings International Workshop on River Basin Management, The Hague, 27-29 October. IHP-V/Technical documents in hydrology, No. 31. International Hydrological Programme. [online] URL: https://hydrologie.org/BIB/Publ UNESCO/TD 031 2000.pdf

Mukhtarov, F. G. 2009. The hegemony of integrated water resources management: a study of policy translation in England, Turkey and Kazakhstan. Dissertation. Central European University, Budapest, Hungary.

Ostrom, E. 1986. An agenda for the study of institutions. Public Choice 48:3-25. http://dx.doi.org/10.1007/BF00239556

Pierre, J., and B. G. Peters. 2000. Governance, politics and the state. Macmillan, London, UK.

Rhodes, R. A. W. 1996. The new governance: governing without government. Political Studies 44:652-57. http://dx.doi.org/10.1111/ j.1467-9248.1996.tb01747.x

Ridder, D., E. Mostert, and H. A. Wolters, editors. 2005. Learning together to manage together: improving participation in water management. University of Osnabrück, Osnabrück, Germany.

Rieu-Clarke, A. 2005. International law and sustainable development. Lessons from the law of international watercourses. IWA, London, UK.

Ross, A., and D. Connell. 2016. The evolution and performance of river basin management in the Murray-Darling Basin. Ecology and Society 21(3):29. http://dx.doi.org/10.5751/ES-08664-210329

Sabatier, P. A. 1992. Book review of "Governing the commons: the evolution of institutions for collective action" by E. Ostrom. Public Administration Review 86(1):248-249.

Sale, K. 1985. Dwellers in the land: the bioregional vision. Sierra Club Books, San Francisco, California, USA.

Schlager, E., and W. Blomquist. 2008. Embracing watershed politics. University of Colorado Press, Boulder, Colorado, USA.

Schmeier, S. 2013. Governing international watercourses. River basin organizations and the sustainable governance of internationally shared rivers and lakes. Earthscan, London, UK.
Skelcher, C. 2000. Changing images of the state: overloaded, hollowed-out, congested. Public Policy and Administration 15 (3):3-19. http://dx.doi.org/10.1177/095207670001500302

Skelcher, C. 2005. Jurisdictional integrity, polycentrism, and the design of democratic governance. Governance: An International Journal of Policy, Administration, and Institutions 18(1):89-110. http://dx.doi.org/10.1111/j.1468-0491.2004.00267.x

Skelcher, C. 2006. Does democracy matter? A transatlantic research design on democratic performance and special purpose governments. Journal of Public Administration Research and Theory 17:61-76. http://dx.doi.org/10.1093/jopart/muj014

Teclaff, L. A. 1967. The river basin in history and law. Nijhoff, The Hague, The Netherlands. http://dx.doi.org/10.1007/978-94-015-1025-7

Thelen, K. 2004. How institutions evolve: the political economy of skills in Germany, Britain, the United States, and Japan. Cambridge University Press, Cambridge, UK. http://dx.doi. org/10.1017/CBO9780511790997

Wittfogel, K. 1957. Oriental despotism: a comparative study of total power. Yale University Press, New Haven, Connecticut, USA. 